Cahiers $d u$ MONDE RUSSE

\section{Cahiers du monde russe}

Russie - Empire russe - Union soviétique et États indépendants

$50 / 1 \mid 2009$

Écrits personnels. Russie XVIII ${ }^{\mathrm{e}} \mathrm{XX} \mathrm{X}^{\mathrm{e}}$ siècles

\title{
Social Categories in Russian Imperial History
}

\author{
Elise K. Wirtschafter
}

\section{OpenEdition \\ Journals}

Édition électronique

URL : https://journals.openedition.org/monderusse/9164

DOI : 10.4000/monderusse. 9164

ISSN : $1777-5388$

Éditeur

Éditions de l'EHESS

Édition imprimée

Date de publication : 31 mars 2009

Pagination : 231-250

ISBN : 978-2-7132-2259-7

ISSN : $1252-6576$

\section{Référence électronique}

Elise K. Wirtschafter, "Social Categories in Russian Imperial History », Cahiers du monde russe [En ligne], 50/1 | 2009, mis en ligne le 01 janvier 2009, consulté le 02 septembre 2022. URL : http:// journals.openedition.org/monderusse/9164; DOl : https://doi.org/10.4000/monderusse. 9164 
Dans cet essai, Elise K. Wirtschafter fait écho à celui de Michael Confino sur les soslovija (états) commme système de classification sociojuridique paru dans le numéro précédent (49/4). Ceux qui désireraient s'associer à cette discussion, la prolonger et l'élargir, sont invités à soumettre leurs propositions. En outre, un numéro thématique «Classifications sociales et juridiques dans l'Empire russe (du XVII à 1917) » est en cours de préparation. (NdlR)

\section{SOCIAL CATEGORIES IN RUSSIAN IMPERIAL HISTORY}

In the 1968 edition of Social Theory and Social Structure, Robert K. Merton writes of middle-range sociological theories that they "consist of limited sets of assumptions from which specific hypotheses are logically derived and confirmed by empirical investigation [...] The middle-range orientation involves the specification of ignorance. Rather than pretend to knowledge where it is in fact absent, it expressly recognizes what must still be learned in order to lay the foundation for still more knowledge. It does not assume to be equal to the task of providing theoretical solutions to all the urgent practical problems of the day but addresses itself to those problems that might now be clarified in the light of available knowledge."' Although Merton's statement refers to applied sociological research, the issue it highlights resonates with historians. In the effort to reconstruct past events, historians are by nature inclined to follow a middle way - a middle way between what current theoretical or intellectual fashion tells us we should want to know and what the documentary source base allows us to know.

Michael Confino's essay on "the soslovie (estate) paradigm" leads readers to the sort of "middle-range" conclusion advocated by Merton. Reflecting upon roughly a century of social discourse and historiographic debate, Confino reminds historians of how difficult it can be to find the appropriate vocabulary for describing the social arrangements of old regime Russia. Like almost every historian of Russia, Confino thinks within the conceptual apparatus of European history. Working with the language of estate (état) and class, he traces the long-term development of Russian society with reference to Muscovite ranks (chiny), Petrine service estates (sosloviia or sostoianiia), and late imperial classes. This is to be expected, given that the established historiography is largely the product of how Russian elites, and consequently later generations of historians, understood these categories. But as Confino also makes clear, the categories and concepts derived from European

1. Robert K. Merton, Social Theory and Social Structure (New York: Free Press, 1968), 68-69. 
history are never quite adequate when applied to the Russian case. Indeed, the "European" categories that Russian historians tend to accept as unproblematic do not even make sense for all of Europe. Still, if scholars are to have a meaningful conversation about Russia, Russia in Europe, Europe, or any particular European country, they need to adopt terminology that, while not exactly precise, is more or less understandable from a variety of historical perspectives. In this spirit, Confino notes that the prerevolutionary historian V.O. Kliuchevskii used the term soslovie to mean not état but social category. Kliuchevskii, Confino insists, would not have employed a term "that was opposed to common usage"; he would not have risked being "misunderstood by his [Russian] readers and listeners." So although the language of soslovie may not be fully satisfactory from the viewpoint of recent scholarship, it "is too well established in the historians' [sic] vocabulary to be abandoned at this late date."'2 The same can be said of chin and class.

If for now historians must accept the language of soslovie as the primary language of Russian social history, this does not mean that better solutions to open questions will not eventually be found. Michael Confino's attention to "open questions," his eagerness to find "a better solution," places him squarely in the methodological middle way, in that shifting ground between what historians would like to know and what they are able to know based on the sources at hand. Indeed, because of the mass illiteracy that persisted for much of the history of Imperial Russia, social historians have been forced to rely on the legal-administrative records of the bureaucracy and/or the letters, memoirs, scholarship, literary works, and journalistic accounts of the educated classes. For historians, sources are everything, and while the collapse of the Soviet Union has produced greater archival access, the parish, estate, and local government records that promise to provide new information are often fragmentary and geographically limited. Still, as researchers continue to investigate these records, and as they apply innovative theoretical perspectives such as those being developed in environmental and regional history, they are likely to discover new answers to longstanding problems. This essay assumes that better solutions will indeed be forthcoming, but it remains within the existing historiography based on official and elite sources. Sensitive to the limits imposed by these sources, the essay seeks to elucidate what they make knowable.

\section{Social Categories and Social History}

In its heyday the "new social history" of the 1960s to 1980s significantly broadened the knowledge base available to scholars. Social historians sought among other things to write "history from below," the history of laboring people as opposed to the history of political and intellectual elites. Grounded in geography, demography, and

2. Michael Confino,"The Soslovie (Estate) Paradigm: Reflections on Some Open Questions," Cahiers du Monde russe, 49, 4 (December 2008): 690, 699. 
economics, history from below also included the history of mentality or social consciousness - the history of how ordinary people understood the social relationships, material conditions, everyday routines, and political arrangements that defined their lives. Over time, work in Russian archives taught historians that the effort to understand the social consciousness of laboring people - people who rarely expressed themselves in writing - had produced valuable information about their relationships to legal-administrative institutions but scant knowledge of their actual thoughts and feelings. Subsequent research in the history of concepts (Begriffsgeschichte) showed that the meanings and definitions of seemingly familiar social categories could be variable even in a single context, suggesting that the relationships they embodied might also be changeable and indeterminate. From these "discoveries" historians concluded that in the search for social consciousness - for what people thought about the social relationships of everyday life - they had analyzed the official conceptualization rather than the lived experience of "society."3 Once scholars understood that government records and other elite sources documented not the full range of social life but the official social order, it became necessary to ask what could be learned from the study of legally defined social categories. What did the essentially official categories reveal about the development of Russian society?

Before addressing this question, it is important to note that the legally defined categories represented just one type of social classification found in Imperial Russia. Socioeconomic and sociocultural categories also developed. Although the legal categories dominate the archival record, and although the specific categories that fall under one or another rubric - legal, socioeconomic, or sociocultural frequently overlapped and intersected, these broad classifications always should be kept in mind. They admit the full range of intellectual conceptions of society found in the historiography and available documentation, and they correspond to the developmental sources of social definition and delineation, the relative weight of which changed depending on context and contiguity. ${ }^{4}$

The legal categories of Russian society defined the formal institutional parameters of individual and collective life chances, including socioeconomic relationships sanctioned or prescribed by law. Such life chances took the form of civic rights, service obligations and opportunities, access to education, inheritance and property rights, rights to trade, and rights of production. Legal categories were the product of state and empire building, which encompassed all types of service, government-sponsored schools, and the incorporation of ethnic and religious minorities.

3. This understanding of Russian social history is presented in Elise Kimerling Wirtschafter, From Serf to Russian Soldier (Princeton: Princeton Univ. Press, 1990); idem, Structures of Society: Imperial Russia's "People of Various Ranks" (DeKalb: Northern Illinois Univ. Press, 1994); idem, Social Identity in Imperial Russia (DeKalb: Northern Illinois Univ. Press, 1997); idem, Russia's Age of Serfdom, 1649-1861 (Malden: Blackwell, 2008).

4. These developmental sources are discussed in Wirtschafter, Structures of Society. 
Socioeconomic categories arose from informal life chances: for example, the need to make a living in specific historical circumstances. The socioeconomic conception depended most directly on environmental conditions, material resources, economic structures, and the organization of families and communities. Socioeconomic categories grew out of spontaneous productive development and relations of production, including illegal and extralegal economic activities such as the unlawful exploitation of serf labor, the "free works" of the regimental economy, and some forms of peasant trade.

Finally, sociocultural categories appeared in response to social and spiritual needs and in order to legitimize power and authority relationships. These categories developed both outside of officialdom and within the framework of state-sponsored educational and artistic institutions. The sociocultural categories encompassed collectivities such as obshchestvo (civil society of the educated), narod (the people), and the intelligentsia. Areas of activity that generated sociocultural categories included religion, the spread of literacy and education, the development of a commercial press, popular culture, the evolution of customary law within individual communities and in relation to statute law and government administration, and the formation of a public or semipublic sphere represented by self-sustaining literary, artistic, and scholarly elites and by cultural, professional, religious, and secret societies.

When historians look at what social categories and definitions meant in concrete historical circumstances - when they consider how specific categories were applied, received, and recreated in government and society - it becomes clear that the understanding and contours of the categories changed depending on how, when, where, by whom, and for what purpose they were used. The resulting patterns and dynamics of social definition indicate that whereas the legal, socioeconomic, and sociocultural modes of categorization tended toward precise delineation, the multiple meanings of individual categories remained contextual and fundamentally indeterminate. For scholars, fluctuations in the meaning of the categories raise interesting questions about standard categorical distinctions that often appear in historical writings (this essay included) - distinctions such as state and society, law and custom, elite and popular, conscious and spontaneous, modern and traditional. The relationship between customary and statute law illustrates the point. In the selection of recruits for the Russian army, popular custom clearly preceded and to some extent determined legal formulations. At the same time, it was state demand that forced local communities to develop conscription practices in the first place. Legal culture in this arena did not, then, consist of two separate spheres, the formal and the customary. It was instead a messy interactive blending and clashing of official and local practices that formed and operated only in relation to each other. Just as individual and community conceptualizations of social relationships, including their own selfdefinitions, represented accommodation or resistance to the social order, legally defined social categories constituted not only compulsion but also compromise with concrete historical conditions. 


\section{Social Categories as Social Process}

Russian archives are filled with judicial cases that document how official social categories operated in concrete circumstances. These cases encompass a broad range of social phenomena, all of which illuminate the relationship of ordinary people to official society: falsified identities, illegal enserfment, popular disobedience and rebellion, peasant complaints against abusive landowners, and soldiers' complaints against negligent and cruel commanders. ${ }^{5}$ To illustrate the relationships and interactions at work, it is worth describing a handful of cases. The first concerns the illegal enserfment of a self-proclaimed soldier's son and thus illustrates the uncertainties of social definition caused by the demands of the service state. The second case, a record of military service and disobedience by soldiers, highlights the ability of Russian subjects to use judicial proceedings to defend individual and collective interests. Finally, the last two cases deal with the relationship between socioeconomic development and social categorization, specifically with how economic relationships undermined official social definitions. One case concerns the illegal ownership of serfs by non-nobles and the other an apparent imposter claiming to be the adopted son of a Moscow townsman. In all of these cases, the relationships and circumstances described seem confusing and convoluted. Rest assured, however, that the messiness is indicative of actual historical reality.

Throughout the Imperial period, military service played an important role both in defining social boundaries and in creating opportunities to cross those boundaries. Decades before the creation of the citizen army of revolutionary France, the Russian empire built a military force based on mass conscription. Dependent upon the institution of serfdom, this army dated from the reign of Tsar Peter I (ruled 1682/1689-1725) and drew its recruits from social groups subject to the Petrine capitation. Most recruits came from the state peasantry or serf population, with a smattering from the urban laboring classes and various minority communities. Service was for life, though in 1793 the government reduced the term to 25 years, followed by a further reduction to 20 years in 1834. Universal conscription did not come into play until 1874, after the 1861 emancipation of the serfs, and only then did it become possible for the empire to maintain a body of reserves ready for call up in time of war.

Serfdom imparted to Russian military service a distinctive set of features. Before the emancipation of 1861, conscription brought "freedom" to hundreds of thousands of laboring people. At the moment of induction, recruits became legally free from the capitation and authority of the landowner or local community. Their

5. Examples of these cases are discussed in E.K. Wirtschafter, "Legal Identity and the Possession of Serfs in Imperial Russia," Journal of Modern History, 70/3 (September 1998): 561-587, and in the studies cited in note 3. On popular use of the courts, see also Jane Burbank, Russian Peasants Go to Court: Legal Culture in the Countryside, 1905-1917 (Bloomington: Indiana Univ. Press, 2004); Alessandro Stanziani, "Serf, slaves, or wage earners? The legal status of labour in Russia from a comparative perspective, from the sixteenth to the nineteenth century," Journal of Global History, 3, 2 (July 2008): 183-202. 
wives and any children born to them (or their wives) after they entered active service also became legally free. Ironically, this freedom usually meant not personal liberty but greater social insecurity. Soldiers' wives who left the village, whether voluntarily or under compulsion, struggled to earn a living and find a place in society. Soldiers' daughters usually remained with their mothers or attended state schools. Soldiers' sons either entered military schools around age 7 or began active service at age 18 . As members of a legally free social category with access to a modicum of education, soldiers' children (soldatskie deti) enjoyed the possibility of upward social mobility. Rarely did they achieve noble status, but soldier's sons could be found in the ranks of noncommissioned officers, in lesser administrative posts, and in Russia's proto-professions.

The illegitimate sons of soldiers' wives also belonged to the category "soldiers' children," and they too were legally free and supposed to enter military service. In practice, their status remained particularly ambiguous. They could be difficult to identify, and landowners who supported them sometimes attained rights of ownership. The uncertainties that arose are illustrated by a case from 1843 heard in the Bronnitsy district court of Moscow province. ${ }^{6}$ A serf named Makei Aleksandrov was brought before the court, accused of striking a peasant official (starosta) and failing to extinguish a fire. Aleksandrov denied his serf origins, claiming instead that he was Makei Filipov, the illegitimate son of a soldier's wife, a status that would have made him a legally free man. The court rejected the claim, and after several peasants testified to Aleksandrov's disorderly and negligent conduct, he was sentenced to 50 blows with birches and returned to his master. Aleksandrov denounced the judgment, and his case was forwarded to the Moscow criminal chamber, which approved the lower court's decision. Undeterred, in September 1844, Aleksandrov petitioned the Moscow military governor-general, who immediately took steps to corroborate the serf's self-proclaimed free status. Perhaps because the manpower needs of the tsarist army always took priority, the governor-general's office treated Aleksandrov's assertions seriously. Provinciallevel authorities instructed their subordinates to investigate Aleksandrov's origins and ordered his master, Provincial Secretary Isakov, to present appropriate documentation.

In Aleksandrov's appeal to the governor-general, he claimed that his birth to the soldier's wife Nastas'ia Nikiforova could be verified in the parish registers of a village in Bronnitsy district. To support this story, Aleksandrov also identified his godparents, an older sister (also illegitimate) who lived on another estate, and several additional relatives, including a son from a forced marriage. Aleksandrov admitted to being registered to Isakov in the eighth revision, and during the judicial proceedings, he continued to make quitrent payments. He insisted, however, that he was a wrongfully condemned free man, prosecuted for his alleged crimes only after initiating an emancipation suit. Clearly, Aleksandrov did not expect to receive fair

6. TGIAgM, (Tsentral'nyi gosudarstvennyi istoricheskii arkhiv goroda Moskvy), f. 16 (Kantseliariia Moskovskogo general-gubernatora), op. 13, d. 449. 
treatment at the hands of local officials. His master was himself an official, friendly with members of the district court. In light of these unjust circumstances, Aleksandrov requested the transfer of his case to another location and written permission to live independently until the authorities reached a final decision. These requests were denied, but district officials, under direct pressure from superiors, continued to seek additional information from Aleksandrov's registered owner.

At this point the archival record falls silent, and it is not known if the governorgeneral's interest in the case produced additional information that confirmed or negated the convicted serf's story. Regardless of the outcome, the tribulations or machinations of Makei Aleksandrov, self-defined as Filipov, demonstrate how state building produced social insecurity and illegal enserfment and how in cases of illegal enserfment the limited right to emancipation could become a means to protect the empire's lowliest subjects.

The ability of humble Russian subjects to use judicial institutions to defend their needs is documented in numerous courts-martial from the decades preceding the emancipation. In a case from 1857, 21 soldiers serving in the Aland fortifications went on trial for disobedience against their commander, Ensign Shchetinin. ${ }^{7}$ On 28 September 1856 Shchetinin had informed his men that supplies were low and that provisions would be obtained from Åbo. The men agreed to use state funds to provide for themselves until the provisions arrived and received money for food through October 8. For the period October 7 to 14, they reportedly bought beef, which was supposed to last until October 21 . The defendants later testified that half the meat was spoiled, but they also had received money to purchase meal and potatoes.

On October 14 the expected supplies did not arrive, and the situation began to deteriorate. The men received additional money on the fourteenth, but when they requested payment on the fifteenth, Shchetinin told them they would have to wait. For two days, the soldiers carried on with their normal duties. Then on the seventeenth, a noncommissioned officer informed Shchetinin that the men of Company No. 4 again had demanded money. Having run out of state funds, Shchetinin distributed his own money for the fifteenth and sixteenth. He also questioned the men of Company No. 4, who complained that they had nothing to eat and already owed local residents money for the past two days. Shchetinin ignored the claim, believing that the men did have access to food and that local residents could wait until the supplies arrived to be reimbursed. He therefore ordered the men back to work. A few men from Companies No. 5, 6, and 7 obeyed the order, but 18 men from Company No. 4 refused and returned to their quarters. Shchetinin then gave them more of his own money for the seventeenth. Meanwhile, soldiers from other companies also began to complain and refuse to work. On October 17, only the men of Company No. 7 and a handful of soldiers from

7. RGVIA (Rossiiskii gosudarstvennyi voenno-istoricheskii arkhiv), f. 801 (Auditoriatskii departament voennogo ministerstva), op. 73 , d. 32 . 
Company No. 6 complied with orders. ${ }^{8}$ Soon after this incident supplies arrived, and Shchetinin took steps to restore his authority. On October 18, when the commander tried to punish 3 "instigators," the men of Company No. 4 refused to allow the punishments. "They did not steal anything," the soldiers insisted. "The tsar did not order us to starve," one gunner added. With that the entire company walked off, and Shchetinin initiated a judicial process.

The military judicial authorities condemned the men of Company No. 4 on two grounds. First, the testimony of other soldiers indicated that the men had sufficient supplies of food. But Shchetinin had not actually inspected Company No. 4, which was quartered at some distance, so it is possible that the men of Company No. 4 lacked supplies. Second, the authorities also agreed with Shchetinin that the men could acquire food on credit from local inhabitants. Regardless, moreover, of the soldiers' actual condition, the lack of food and funds did not justify disobedience, especially because the situation resulted from circumstances beyond Shchetinin's control. In general, when state supplies were unavailable, military units obtained goods from local residents. Sometimes soldiers also earned money at outside work. Still, if local residents actually had provided adequate food, why did Shchetinin distribute his own money? The archival record does not answer this question.

More interesting than the problem with supplies is what the case reveals about the soldiers' social attitudes and expectations. It is noteworthy that the men of Company No. 4 acted as a unit, that the authorities identified them as such, and that the men of other companies followed their lead. The crime of Company No. 4 consisted of demanding money allotted by law to every soldier. The soldiers knew that their commander was responsible for feeding them and thus refused to work when they did not receive their daily allowance. They also shielded their comrades from punishment: the soldiers had a right to the money and so did not consider their fellow servicemen guilty or any punishment justified. Repeatedly, in the prereform army, soldiers committed acts of disobedience when their rights were violated when their commanders abused them, neglected to provide for them, or punished them unjustly.

The Russian government saw things differently. Disobedience could not be tolerated, though if a commander's negligence or abuse caused the disobedience, he too would be punished along with his subordinates. Of course, the severity of the punishment varied, depending on the crime and social status of the defendants. In this case, Ensign Shchetinin faced two weeks under arrest for "inefficiency" in provisioning his unit. By contrast, 18 men from Company No. 4 were found guilty of "overt disobedience" and sentenced to run the gauntlet 2-4 times through 100 men, followed by 3-5 years of service in a convicts' company. Four of the men were judged medically unfit to undergo corporal punishment and so escaped that part of their sentence. Several soldiers from Companies No.5 and 6 faced milder punishments, and two noncommissioned officers suffered demotion and transfer

8. Note that the facts of the cases are not always clear from the archival record. Here the details regarding the events of October 17 seem muddled. 
for failing to ensure that their subordinates returned to work. Despite the harshness of the punishments, the case illustrates how judicial proceedings afforded ordinary soldiers a measure of protection. In theory and practice, military justice sanctioned expectations of decent treatment and economic security.

In the two cases just discussed, Russian subjects used official social definitions, the terms of military service, and established judicial procedures to protect and defend their interests. In other cases, individuals manipulated social definitions and openly violated legal prescriptions. The exploitation of serf labor by non-nobles shows just how easy it could be to ignore official social boundaries. In a protracted and complicated case spanning the years from 1827 to 1840 , successive administrative decisions and legislative enactments recorded the plight of 26 peasants who claimed to be in the illegal possession of Ipat Koronovskii, a townsman from Vitebsk province. ${ }^{9}$ The facts of the case documented a web of illegal relationships resulting from debt, inheritance, bureaucratic corruption or incompetence, and blatant disregard for the law. The lawsuit that finally decided the case began in 1827, but local officials already had begun an investigation in 1816, after peasants complained of cruel beatings and excessive workloads at the hands of Koronovskii. The investigation revealed that in 1798 the father of Ipat, Lev Koronovskii, acquired 26 serfs from a noblewoman named Katerina Stupishina. Formal deeds registered the peasants to State Councilor Nikolai Volkov. Then in 1799 Lev purchased additional serfs from Stupishina, this time an entire estate with 265 serfs in Velizh district. This sale too was certified in the name of a nobleman, Collegial Assessor Bykovskii. Legal formalities notwithstanding, Lev proudly proclaimed his ownership by renaming the estate L'vov.

Consistent with the façade of ownership, Lev Koronovskii repeatedly bought, sold, and deeded serfs, as if he were a legitimate noble serf owner. In 1804 he sold 3 serfs to a merchant from Smolensk province, Semen Bagreev. In 1818 Bagreev freed one of the serfs, a woman who received a certificate of emancipation from the Velizh city police and subsequently married a local townsman. When Bagreev died, his nephew inherited the remaining two serfs. A second transfer of serfs from Lev occurred when his daughter Pelageia married a nobleman named Bykov and received a dowry of 29 serfs from her father's estate. Lev's testament of 1810 granted her full control over the serfs, and a separate proxy (doverennost') registered with the Velizh city police authorized her to sell them. Any income received from such a sale would count toward the repayment of a debt owed to Pelageia by Collegial Assessor Bykovskii, the registered owner of the serfs.

After the death of Lev Koronovskii, his son Ipat became master of L'vov. Ipat held no proxy from Bykovskii, but in 1811 he sold a male peasant to the townsman Timofei Bagreev, presumably the nephew of the merchant Semen Bagreev. Once again authorities in Velizh, this time the city magistracy, registered the transaction. Collegial Secretary Radkevich subsequently purchased this peasant, and

9. RGIA (Rossiiskii gosudarstvennyi istoricheskii arkhiv), f. 1149 (Departament zakonov gosudarstvennogo soveta), op. 2, d. 20,1.14-17ob. 
investigators also later discovered that the Koronovskiis had sold individual serfs to two other nobles. Finally, in 1812 Ipat hired a steward to manage his estate, an arrangement (uslovie) also duly recorded by the Velizh city magistracy.

To resolve what appeared to be an egregious case of illegal ownership of serfs by non-nobles, local authorities first needed to determine who actually possessed the estate and serfs in question. The paper trail of registered documents recognizing the sale of serfs to non-nobles represented one body of evidence. When officials questioned the peasants transferred to Lev Koronovskii from Katerina Stupishina, all testified that the Koronovskiis were their masters and that both father and son repeatedly reminded them of Lev's purchase. Local parish records likewise identified the serfs of $\mathrm{L}^{\prime}$ vov as the property of the Koronovskiis. Finally, the peasants of neighboring landowners, a townsman who sold liquor on the estate, and two hired stewards confirmed that the serfs belonged to the Koronovskiis. As one steward pointed out, Ipat Koronovskii regularly collected income and taxes from his peasants.

Not surprisingly, the land court concluded that Ipat Koronovskii was the actual owner of the peasants in question. But because Ipat was a townsman, his ownership was illegal. Thus in 1819 his estate came under official supervision with its revenues assigned to the board of social welfare. Eight years later the Senate issued a final ruling: the land and serfs inherited by Ipat from his father belonged to the state, and Ipat himself faced 12 weeks in prison for abusing his peasants. An amnesty of 1826 spared him incarceration, though his former serfs were instructed to submit a formal claim for the value of the grain and other property collected from them. The sum would then be levied against Koronovskii. Because Ipat's sister had become ennobled through marriage, she was permitted to keep her serfs. The noblewoman Katerina Stupishina, who had sold the serfs to Lev Koronovskii, admitted committing perjury. She and the local officials who registered illegal documents also were freed from punishment based on the 1826 amnesty. There were no accusations of bribery arising from the case.

In the end, after untangling the violations of the Koronovskiis and others, officials also reviewed the status of the serfs who had been sold to third parties. Because of the complexity of the case, the Senate allowed nobles who had acquired serfs directly or indirectly from the Koronovskiis to retain possession. Any serfs currently in the hands of non-nobles were to be freed. Roughly 20 years before the emancipation of Russia's serf population, the nobility's exclusive right to serf ownership continued to be violated. Given that years passed before officials unraveled the Koronovskii case, one wonders how many similar cases remained undiscovered or unresolved. That such phenomena occurred on a wider basis seems certain. According to one scholarly study, in the period 1835-1858, provincial-level courts heard 20 thousand and the Senate 15,153 cases involving claims of unlawful enserfment and illegal bondage. ${ }^{10}$

10. Steven L. Hoch and Wilson R. Augustine, "The Tax Census and the Decline of the Serf Population in Imperial Russia," Slavic Review, 38, 3 (September 1979): 403-25. 
Another colorful case, also the product of economic relationships, concerned an apparent imposter who attempted to register in the townspeople of Arkhangel'sk by identifying himself as Filipp Grigor'ev Simonov, the adopted son of a Moscow townsman. ${ }^{11}$ In 1846 Filipp journeyed to Arkhangel'sk with a merchant employer. At the time, he carried a passport issued by the Moscow city duma and receipts confirming the payment of all taxes. When Filipp requested registration in the city of Arkhangel'sk, authorities sent inquiries to their Moscow counterparts. Moscow officials declared the man an imposter, as did his alleged adoptive mother. The woman reported that she had lived with her son, the real Filipp Grigor'ev, who now was married and himself a father.

The ensuing investigation exposed numerous anomalies and contradictions. Several intermediaries had helped to formalize the identification papers of the imposter - the Arkhangel'sk Filipp - but key witnesses had died or been drafted into the army. Officials never definitively established the facts of the case. It is possible that the merchant who originally employed the Arkhangel'sk Filipp had taken advantage of an error in the Moscow city records, which listed two Filipp Simonovs. Because of the double entry, the merchant was able to obtain a passport for a fourteen-year-old boy of unknown origins, the present Arkhangel'sk Filipp. The case dragged on for years, and in 1860 officials in Arkhangel'sk finally abandoned their efforts to determine the identity of the Arkhangel'sk Filipp. They concluded that so young a boy could not have falsified his origins deliberately. Nor, given his documented association with the Moscow city government, could he be regarded as a vagrant or runaway. Perhaps with some monetary encouragement from Filipp's merchant patron, officials allowed the imposter to register. The archival document preserved in Moscow records that "the Arkhangel'sk society of townspeople has declared its agreement to accept him into the townspeople of the city of Astrakhan [sic]." It remains unclear whether the mention of Astrakhan represents a scribal error or an effort by Arkhangel'sk officials to cover their tracks.

The above cases illustrate, and historians long have recognized, that the legally defined categories of Russian Imperial society did not necessarily correspond to social and economic facts. In the minds of some scholars, the gap between legal definitions and concrete realities may raise questions about the methodological usefulness of official categories. There are, however, several reasons why the categories should be incorporated into any understanding of Russian society. First, the categories had multiple usages and meanings. They were defined, applied, and manipulated in varied and often contradictory ways both by the government and by individuals and collectivities in society. Second, and this point deserves emphasis, historians are not free to abandon the language of their sources. They may, however, treat these sources as language, not as transparent reflections of reality, and they must examine what the official categories represented in specific historical circumstances. Regardless of empirical facts, the categories articulated an intellectual vision, and as such, became part of the social landscape. Finally, the 
categories operated primarily in the context of the official social order and of society (obshchestvo) or local particularistic societies (obshchestva) in the formal sense. The categories were much less relevant to the intimate sphere of social life, though because they encompassed men, women, and children together, they also played a role in the intimate sphere. That they were official or legal did not render them nonsocial or nonsocietal. They were reactive, interactive, changeable, porous, and ambiguous. They were continuously in process, and just because they served administrative aims did not mean that they lacked social meaning. To paraphrase Catherine II's apocryphal remarks to Denis Diderot: lawmakers did not write on blank paper; they wrote on human skin. ${ }^{12}$

The workings of Russian society are best understood when historians think of the official categories as a form of social process. The conceptual plasticity of the categories shows that they were never transparent mirrors of social life. They were representations, perceptions, conceptualizations, and images of social life that at once reflected, created, and were transformed by dynamics of development and interaction in society. A person's position in the social order constituted a bundle of ascribed definitions and self-definitions, and the ways in which individuals and collectivities identified themselves depended on context and contiguity. Whether social definitions were official, societal, or personal, they were socially meaningful only in relation to someone or something - be it the peasant village or commune, the landlord or local official, the conscription board or district court, a subordinate or superior, a fellow officer or soldier, a noble acquaintance or friend, a neighbor or colleague, a teacher, relative, spouse, or child. Even if the legally defined categories were not internalized as social consciousness, they remained fundamental to the life chances of individuals and collectivities throughout the Imperial period.

\section{Social Categories and Societal Integration}

Because of the porosity, amorphousness, and malleability of Russia's official social categories, they functioned as an effective source of societal integration. In some contexts this was an imposed integration, which then also might encourage social conflict and resistance. In others, the categories provided mechanisms for both formal and informal integration. It is possible to glimpse this integrative role in the ways that society received and used the official categories. This does not mean that the categories became internalized in the self-definitions and social identities of

12. "Monsieur Diderot, I have heard with the greatest pleasure that which your brilliant mind has inspired in you, but with all your great principles, which I understand very well, one would make beautiful books and bad works. You forget in all your plans of reform the difference between our two positions; you, you only work on paper, which bears everything; it is all smooth, supple, and opposes no obstacles, neither to your imagination nor to your pen; while I, poor empress, I work on human skin, which is quite otherwise irritable and ticklish." Quoted in Larry Wolff, Inventing Eastern Europe: The Map of Civilization on the Mind of the Enlightenment (Stanford: Stanford Univ. Press, 1994), 230. 
individuals or collectivities. It does mean, however, that in their responses to and adaptations of legal definitions, Russian subjects appropriated the categories for their own purposes, forcing policymakers and administrators to react to the unforeseen consequences of societal interpretations. As numerous judicial cases make clear, individuals and groups in society invoked the official categories, claiming legal identities and their attendant rights, in order to survive, prosper, resist authority, and negotiate position within the framework of the social order.

Still, what is one to make of the legal status or "rights" of Russian serfs and other laboring people? What did "rights" amount to in an absolutist monarchy founded on the institutionalization of human bondage? Years ago Marc Raeff described how tsarist officials influenced by cameralist thinking sought to establish a well-ordered state, society, and serfdom. ${ }^{13}$ Their goal of educating "citizens," mobilizing resources, and reforming institutions required government grounded in the rule of laws. The rule of laws is not equivalent to the rule of law, yet throughout the Imperial period, enlightened bureaucrats made a genuine effort to formulate and implement just, or at least effective, laws. ${ }^{14}$ At the same time, it is important to remember that officials frequently applied the laws in haphazard and irregular ways. Arbitrariness resulted not only from corruption, but also from limited experience of legal codification and from the absence of a clear distinction between legislative, administrative, and judicial authority. Court records repeatedly show that if justice or the fulfillment of duty required violations of the law, such violations might be tolerated. The abstract goal of justice, however defined, took precedence over strict adherence to the law. Indeed, "justice" frequently required the bending of laws.

The possibility of obtaining justice based on legislative prescriptions did not, then, eliminate arbitrariness or abuse. It did, however, define a moral standard that legitimized and encouraged popular action. Despite unpredictable and statistically meager results, Russian subjects repeatedly appealed to the image of the good and merciful tsar in the hopes of achieving redress for grievances. If individuals did not actually believe in the tsarist principle, they nevertheless used it in practical ways to demand just amends. This was not due to so-called "naïve monarchism" or to a "myth of the tsar." It resulted from the simple fact that final judicial and legislative authority lay in the hands of the ruler. The monarch was bound to obey the laws, though prior to the creation of the Duma in 1906, he or she also could change the laws at will. For almost the entire Imperial period, no administrative ruling or statute became law without first receiving the monarch's "so be it." In addition, the sovereign could at any moment overrule any and all legal-administrative decisions emanating from any state or societal institution. In the name of justice and mercy, monarchs intervened in the routine operations of government, and outside regular

13. Marc Raeff, The Well-Ordered Police State: Social and Institutional Change through Law in the Germanies and Russia, 1600-1800 (New Haven: Yale Univ. Press, 1983).

14. By referring to the "rule of laws," as opposed to the "rule of law," I hope to convey the distinctiveness of the Russian case (in Europe) without, however, suggesting that the empire was lawless or its officials and subjects devoid of legal-mindedness. 
bureaucratic channels, they responded to the petitions of individual subjects and communities. No matter how absolutist the institutions of the monarchy remained, the art of governance - the need to project legitimate state power - produced ongoing "dialogue" with the Russian people.

The dialogue between the Russian monarchy and the people, the monarch's subjects, assumed a variety of forms. Given the absence in Russia of constituted bodies, codified feudal contracts, and time-honored legal rights, this dialogue is best understood as a moral one. Already in Muscovite times and continuing until 1917, the Russian monarchy consulted representatives of social groups, local communities, and central institutions on an ad hoc basis, in times of national emergency and in preparation for major reforms and legislative initiatives. Before 1906 , society's voice was not formalized or institutionalized on any permanent translocal basis, but consultation was practiced. Equally significant, because ordinary people were able to manipulate legal prescriptions for personal gain, they too played a role in the "legislative process." Repeatedly, policymakers issued new laws in response to popular interpretations of legal formulas. This dynamic is clearly visible in military judicial records and in the legislation governing peasant lawsuits on grounds of illegal enserfment.

Technological and institutional obstacles to the implementation of legislative enactments also defined interactions between the monarchy and the people. Limits to the effective exercise of state power left enormous discretionary authority in the hands of landowners, military commanders, and local officials. Although discretionary authority could be arbitrary and corrupt, the wide latitude given to local communities also promoted societal integration by granting a measure of autonomy to social groups. Again, in the absence of constituted bodies such as guilds, diets, parlements, provincial estates, estates general, or the English parliament - bodies that linked the localities to each other and to the state authority relationships tended to operate on a local, informal, and personalized basis. Unlike their English or French counterparts, who appropriated locally constituted bodies in order to extend monarchical power, Russia's rulers had no such bodies to appropriate. Within the confines of Russian absolutism, state power remained remote and relatively easy to evade. Institutional fragmentation and ineffective administration brought de facto "freedom."

But freedom by default is not equivalent to limited monarchy or politically organized civil society, two mainstays of modern democratic development in Europe. The institutionally fragmented Russian monarchy was built upon a similarly fragmented Russian "society" - a society that before the early twentieth century possessed no translocal authority or representation. The legally defined categories or identities of Russian Imperial society (and of Imperial society more broadly) functioned as tools of administrative control and governance: they defined formal rights and obligations - for example, tax and service obligations - as well as lawful economic opportunities and access to education and the rewards of service. They also represented social tools that people could appropriate and manipulate as they struggled to negotiate authority 
and survive economically. Social meaningfulness did not require that people internalize the categories as social consciousness. Nor did it require that the categories be the product of societal initiative. Whichever self-definitions people chose, and they chose differently in different situations, the legal categories represented an important dimension of social life. For most of the Imperial period, these identities provided the only continual and comprehensive evidence of how educated Russians conceptualized their society. Such conceptualizations then served as a basis for policymaking and social action. In addition, because ordinary people could employ tsarist laws for their own purposes, their use of official social categories, like their use of the courts and the idea of the good tsar, integrated them into the Imperial polity.

When the plasticity of official social categories encouraged accommodation and adaptation, legal ambiguity created opportunity. But legal ambiguity also produced uncertainty, instability, and societal fragmentation. For this reason, it is difficult to conclude that in the post-emancipation period, economic modernization, mass education, or intensified geographic and social mobility undermined the stable social bonds and identities of "traditional" society. Russian society was traditionally fragmented, and the "traditional" identities that according to some historical accounts appeared to be crumbling had in fact never been firmly established. Nor were the "moral economies" and "everyday forms of resistance" of late Imperial peasants, workers, or soldiers fundamentally different from those that existed prior to the Great Reforms. This is illustrated by popular uprisings, soldiers' complaints against officers, peasant lawsuits seeking emancipation, and the still virtually unstudied relationship between state demands, community practices or customs, and statute law. Without pressing the point, it can be noted that the social foundations of the Russian Revolution(s) had as much to do with already weak institutions as with new social fissures.

\section{Social Categories and Social Insecurity}

At the same time that social amorphousness promoted societal integration by allowing people to elude administrative controls and reinvent their identities in creative and profitable ways, it also produced widespread insecurity. This is nowhere more evident than in the status of the empire's most privileged social group, the nobility. Throughout the Imperial period, Russia's landowning and service elites remained legally and, with significant exceptions, economically vulnerable. Ennoblement occurred only through service (except for women, who could achieve ennoblement through marriage), and noble rights, even when hereditary, were defined and at any moment could be changed by the monarch's decree. Unlike the aristocracies and nobilities of England, France, the German states, and the empire's own Baltic provinces, Russian nobles lacked proprietary claims to authority beyond the family estate - claims that were historically articulated and politically constituted in the local laws, offices, and institutions of 
an identifiable territory. Not even the legal identity of Russian nobles could always be ascertained. In the early eighteenth century, unrequited claimants to noble status found themselves inscribed in poll tax registers, the primary marker of lower-class status, and a century later, noble claimants still might be denied access to service with noble rights. Adding to the uncertainties of definition, ambitious and clever commoners falsified identities and illicitly assumed the attributes of nobility. These conditions are difficult to measure, but as late as 1767, both the Heraldry Office and the Senate complained about the absence of a complete register of nobles and requested an exact definition of whether the qualifications for nobility should be service rank, possession of an estate, or both. ${ }^{15}$

The social characteristics of the nobility were similarly ambiguous. The reforms of Peter the Great added a cultural component to noble identity by imposing European education and forms of sociability on elite courtiers and servicemen. Even so, landed nobles of exalted lineage sometimes remained poor, uneducated, and steeped in custom. In Sergei Aksakov's novel A Russian Gentleman, the family of Sophia represents the post-Petrine urban, bureaucratic nobility. Based on education and the possession of European culture, Sophia regards her background as superior to that of many lineal nobles. ${ }^{16}$ Indeed, although her husband's ancestors are of ancient and honored lineage, her father-in-law, the patriarch Bagrov, and his married daughters live in a manner barely distinguishable from that of peasants. Genealogies notwithstanding, Sophia's father, a parvenu noble, questions whether or not the Bagrovs, given their ignorance and boorishness, offer a suitable match for his sophisticated daughter. The marriage illustrates how Western/European culture, both spiritual and material, compensated for, and in the eyes of some took precedence over, lineage and wealth.

The association of social status with culture was particularly striking in the development of the intelligentsia and a self-consciously independent society, two sociocultural categories that overlapped with the nobility. By the mid-eighteenth century, Russia possessed a socially mixed, enlightened reading and writing public that distinguished itself from corrupt courtiers and uncultivated groups in society. In the early nineteenth century, educated people identified with the concept of a polite society, also separate from the monarchy and state, which they defined in terms of moral autonomy, European culture, and refined sociability. By 1861 the collective concept of the intelligentsia, known for its ethos of service to the people, entered the empire's social vocabulary. In these and other examples, educated Russians engaged in an ongoing search for meaningful social ties by conceptualizing sociocultural collectivities beyond kinship, immediate community, and official society. Through identification with the "honorable public" (publika), "civil society of the educated" (obshchestvo), the intelligentsia, and later the nation or the people (narod), educated Russians articulated identities

15. Wirtschafter, Social Identity, 29-32

16. S.T. Aksakov, A Russian Gentleman, trans. J.D. Duff (Oxford: Oxford University Press, 1982). 
that conveyed a sense of social belonging without, however, attaining an independent institutional existence. Only in the later nineteenth century did the self-proclaimed sociocultural identities of Russia's educated elites acquire firm institutional moorings. Only then did their prepolitical discursive ideal become a nascent civil society.

Questions of the public, the public sphere, and civil society have captivated social and cultural historians for the past several decades. The existence of a public sphere and/or civil society has been widely recognized as an essential element of liberal democratic development in modern Europe. In nineteenth-century Russia, despite a rich network of voluntary associations, the persistence of police repression and absolutist monarchy clearly impeded the formation of a politically organized civil society. But while such impediments are significant, they cannot explain why Russia's educated and professional classes disintegrated into internal crisis and conflict at the very moment when the revolution of 1905 allowed them relatively free association. In the realms of economic activity (some of it illegal), local self-government, philanthropy, cultural creativity, and even professional services, the roots of Russian civil society seemed viable and broadly rooted from at least the mid-nineteenth century. ${ }^{17}$ Still, this "civil society" failed to cohere and sustain a translocal presence in the political public sphere. Instead, until the period of the Duma monarchy (1906-1917), it remained the stuff of private, personalized, and localized relationships.

Given the lack of formal institutionalization in Russian social and political life - again the absence of translocal constituted bodies proved crucial - it was not evolving social institutions that rendered society into a whole and bound it to government. Rather, the cement of society emerged from judicial process, legally defined social categories, the Orthodox religion, and increasingly, Russian literature and culture. Because the institutions of central government barely reached beyond provincial and district capitals, extensive informal autonomy remained in the hands of local communities. This informal autonomy is particularly important for understanding how the Imperial polity functioned over the long duration. Ultimately, however, it was the lack of formal institutionalization and the weak linkages between the center and localities that accounted for the deep social crisis and ideological voluntarism of the revolutionary era. In the late nineteenth and early twentieth centuries, a politically organized civil society finally emerged, at the same time that the cumulative effects of resource mobilization, universal conscription, and more than two centuries of state building brought growing numbers of Imperial subjects into direct contact with governmental authority. In these conditions of unprecedented societal assertiveness and mounting bureaucratic

17. For recent treatments, see Joseph Bradley, Voluntary Associations in Tsarist Russia: Science, Patriotism, and Civil Society (Cambridge: Harvard Univ. Press, 2009); B. PietrowEnnker and G.N. Ul'ianova, eds., Grazhdanskaia identichnost' $i$ sfera grazhdanskoi deiatel'nosti v Rossiiskoi imperii: Vtoraia polovina $X I X$-nachalo $X X$ veka [Civic Identity and the Sphere of Civic Activity in the Russian Empire: Second Half of the Nineteenth-Beginning of the Twentieth Century], (M., 2007). 
intrusions into everyday life, the gap between the idea and reality of tsarist rule became increasingly apparent. Not surprisingly, belief in a beneficent monarch steadily eroded.

\section{Conclusion}

Attention to the amorphousness of Russia's legally defined social categories suggests a possible solution to the problem of the historian's social vocabulary. The amorphousness indicates that the languages of soslovie and class both are needed, depending of course on concrete circumstances. The social crisis of late Imperial Russia cannot be explained with reference to a succession or layering of distinct social formations such as the transition from pre-modern/legal sosloviia to modern/economic classes. Ranks, sosloviia, and classes all held meaning and all played a role in the ordering of Russian society throughout the Imperial period. One must add, moreover, to the list of social "formations" entities such as the patriarchal household, the parish or church community, and the sociocultural identities associated with obshchestvo, the intelligentsia, and the narod. Each of these categories illuminates specific social relationships and patterns of development. That one type of category formed or functioned at a given moment did not require that another type be superseded or disappear. The same can be said of the chronological divides employed by historians. Like social categories, chronological divides are needed, if scholars are to discuss events and people in specific historical settings. But chronological distinctions also can be arbitrary and variable, depending on circumstances and the subject in view. That great divide of Russian Imperial history, the 1861 emancipation of the serfs, represented both a dramatic break on the model of 1789 (except that Russia's old regime lasted until 1905) and the initiation of an emancipation process that absent war and revolution would have continued well into the twentieth century. Social categories and chronological divides are necessary tools of analysis and communication, but they are not equivalent to concrete historical facts.

Is it, then, inevitable that the legal-administrative record of the tsarist bureaucracy will produce nothing more than a statist or official understanding of Russian social history? Historians can know only that which their sources make knowable, and people who do not express themselves in writing reveal only so much. Baffled by the limits of social history, particularly its rigorous standard of evidence, scholars began in the 1980s to move into the more supple arena of cultural history, a subfield influenced less by sociology and economics and more by anthropology and literary criticism. As cultural historians, scholars continued their search for social consciousness, now labeled discourse analysis, subaltern studies, popular culture, the history of mentality, or the history of everyday life. Through the study of events and cultural artifacts as "representations" or narratives that can be "read" in multiple and creative ways, historians sought to reconstruct the mentality of individuals and the mores of social collectivities by uncovering the 
symbolic meaning(s) of human actions. ${ }^{18}$ But here too, as in the archives, the Russian sources refused to replicate social consciousness. Once again, subjective thoughts and feelings remained inaccessible. As a result, it became necessary to think in terms of public as opposed to private personhood and to focus on the cognitive question of how people reconciled the idea of society with the reality of social experience. Once again, the history of modern Russian society could not be understood without reference to the history of conceptualizing that society.

The conceptualization of Russian society can be traced through successive generations of intellectuals and rulers. From the time of Peter the Great to the era of Gorbachev, and including the reigns of Catherine the Great and Alexander II, as well as the dictatorships of Lenin and Stalin-Russia's rulers have consciously and often with great violence pursued plans to remake society in accordance with cameralist, Enlightenment, or Marxist principles. Following decades of research devoted to legally defined social categories, historians have learned much about the conceptualization of that society. Through their efforts, it has become clear that in order to understand the structure(s) of a society, it is necessary to examine the language, categories, and concepts employed by contemporaries to describe themselves and their surroundings. Indeed, even if the self-representations of individuals and communities are less objectively accurate than the statistical methods and "scientific" accounts of present-day researchers, they still bear a closer relationship to the behavior, actions, and attitudes of actual historical actors. More often than not, in real historical time, their representations and (mis)understandings constituted the basis for individual and group responses to concrete conditions.

Let the record be clear. To analyze the relationship between social concepts and social realities is not to understand social consciousness. Still, one can take comfort in the realization that what people say and do in public, as opposed to what they really think and feel, is the more crucial factor for explaining how a society and polity function. One can take added comfort in the popular adage that "history repeats itself," despite the well nigh universal condemnation of this notion among professional historians. Historians rightly seek to avoid deterministic and reductive thinking, but their empiricist orientation should not obscure the substantive meaning of "history repeats itself." The cliché suggests that history as a mode of inquiry does more than attempt to understand the past: it leads to the deeper question of "what is there in me that allows me to understand them?" With this

18. E. Wirtschafter, The Play of Ideas in Russian Enlightenment Theater (DeKalb: Northern Illinois Univ. Press, 2003); Richard S. Wortman, Scenarios of Power: Myth and Ceremony in Russian Monarchy, 2 vols. (Princeton: Princeton Univ. Press, 1995 and 2000); E.N. Marasinova, Psikhologiia elity rossiiskogo dvorianstva poslednei treti XVIII veka (Po materialam perepiski) [Psychology of the Elite of the Russian Nobility in the Last Third of the Eighteenth Century (Based on Correspondence)] (M.: Rosspen, 1999); Andrei Zorin, Kormia dvuglavogo orla... Literatura i gosudarstvennaia ideologiia v Rossii v poslednei treti XVIIIpervoi treti XIX veka [Feeding the Two-Headed Eagle... Literature and State Ideology in Russia in the Last Third of the Eighteenth-First Third of the Nineteenth Century] (M.: Novoe Literaturnoe Obozrenie, 2001). 
question history does not simply assess but directly confronts the past by requiring its practitioners and readers to ask of themselves "where would I have been?" By confronting the past, ideally on its own terms, we in fact confront our own moral universe in order to understand where we stand and where we hope to go. In this sense history repeats itself, and the search for social consciousness becomes the search for ourselves.

California State Polytechnic University, Pomona

Department of History

ekwirtschaft@csupomona.edu 